\title{
Compliance with guidelines for emergency management of asthma in adults: experience at a tertiary care teaching hospital
}

\author{
Valerie F. Krym, MD, MPH; ${ }^{*}$ Brent Crawford, MD; ${ }^{\dagger}$ Russell D. MacDonald, MD, MPH
}

\begin{abstract}
Objectives: Despite evidence-based clinical practice guidelines for the emergency management of asthma, substantial treatment variation exists. Our objective was to assess compliance with the Canadian Association of Emergency Physicians (CAEP) / Canadian Thoracic Society (CTS) Asthma Advisory Committee's "Guidelines for the emergency management of asthma in adults" in the emergency department (ED) of a university-affiliated tertiary care teaching hospital.

Methods: This retrospective study was conducted in a Canadian inner city adult ED. Investigators reviewed all ED records for the period from Jan. 1, 2001, to Dec. 31, 2001, and identified adult patients (i.e., $>18$ years of age) with a primary ED diagnosis of asthma. Hospital records were then reviewed to document compliance with the CAEP/CTS asthma guidelines. Descriptive statistics, including means, standard deviations and frequencies were used to summarize information.

Results: Overall compliance with the guidelines was $69.6 \%$, (95\% confidence interval, $64.7 \%-74.5 \%$ ), but compliance ranged from $41.4 \%$ for severe asthma, $67.1 \%$ for moderate asthma, and $88.6 \%$ for mild asthma. Interobserver reliability for compliance assessment was excellent.

Conclusions: Despite publication and dissemination of evidence-based guidelines for the management of acute asthma in adults, guideline compliance at a university-affiliated, inner city, tertiary care teaching hospital ED is suboptimal.
\end{abstract}

Key words: asthma; practice guideline; critical pathways; emergency medicine

\begin{abstract}
RÉSUMÉ
Objectifs: Malgré la diffusion de recommandations de pratique clinique fondées sur des preuves pour la prise en charge de l'asthme à l'urgence, des variations thérapeutiques importantes existent. Notre objectif était d'évaluer l'adhésion aux Recommandations de prise en charge de l'asthme chez l'adulte de l'Association canadienne des médecins d'urgence (ACMU) / Société canadienne de thoracologie (SCT) au département d'urgence (DU) d'un hôpital universitaire de soins tertiaires.

Méthodes : La présente étude rétrospective fut menée au DU d'un hôpital canadien pour adultes en milieu urbain. Les chercheurs effectuèrent la revue de tous les dossiers du DU pour la période

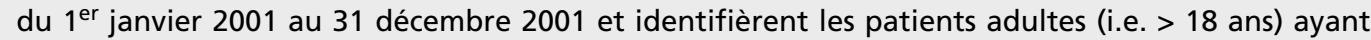
reçu un diagnostic primaire d'asthme. Les dossiers d'hôpital furent ensuite étudiés afin de noter
\end{abstract}

\footnotetext{
*Department of Community Health Sciences, Faculty of Medicine, University of Manitoba, Winnipeg, Man., and Department of Family and Community Medicine, Faculty of Medicine, University of Toronto, Toronto, Ont.

tDepartment of Family Medicine, Faculty of Medicine, University of Manitoba, Winnipeg, Man.

¥Division of Emergency Medicine, Department of Medicine, Faculty of Medicine, University of Toronto, Toronto, Ont.; Ontario Air Ambulance Base Hospital Program, Division of Prehospital Care, Sunnybrook and Women's College Health Sciences Centre, Toronto, Ont.
}

Received: Aug. 18, 2003; final submission: Apr. 19, 2004; accepted: Apr. 21, 2004

This article has been peer reviewed.

Can J Emerg Med 2004;6(5):321-6 
I'adhésion aux recommandations de prise en charge de l'asthme de I'ACMU/SCT. On eut recours aux statistiques descriptives, notamment aux moyennes, aux écarts-types et aux fréquences pour résumer l'information.

Résultats : L'adhésion globale aux recommandations était de 69,9\% (intervalle de confiance de $95 \%, 64,7 \%-74,5 \%)$, mais l'adhésion variait entre $41,4 \%$ dans les cas d'asthme grave, $67,1 \%$ dans les cas d'asthme modéré et $88,6 \%$ dans les cas d'asthme bénin. La fiabilité inter-observateurs quant à l'évaluation de l'adhésion était excellente.

Conclusions: Malgré la publication et la diffusion de recommandations fondées sur des preuves de prise en charge de l'asthme aigu chez l'adulte, l'adhésion à ces recommandations au DU d'un hôpital universitaire de soins tertiaires en milieu urbain est sous-optimale.

\section{Introduction}

Each year in Canada, approximately 400 to 500 people die from asthma, and 78400 are admitted to hospital with an acute exacerbation of disease. ${ }^{1}$ Asthma morbidity is increasing, ${ }^{2}$ and, until recently, so has asthma mortality. ${ }^{3,4}$ The total estimated cost of treating asthma in Canada exceeds half a billion dollars annually. ${ }^{5}$

To improve and standardize care, expert panels have developed evidence-based clinical practice guidelines for the management of asthma in adults. ${ }^{6-9}$ Despite these, considerable variation in patient management still exists, and emergency department (ED) treatment processes are inconsistent. ${ }^{10}$ Standardized ED management processes for acute asthma are feasible and worthy of investigation. Compliance with recommended guidelines may enhance the quality of care, improve patient outcomes and decrease the economic burden of asthma on the health care system. ${ }^{11-13}$ The goal of this study was to assess compliance with the Canadian Association of Emergency Physicians (CAEP) / Canadian Thoracic Society (CTS) Asthma Advisory Committee's "Guidelines for the emergency management of asthma in adults" (Table 1) at a Canadian tertiary care teaching hospital. ${ }^{6,7}$

\section{Methods}

This retrospective study was conducted in the ED of Winnipeg's Health Sciences Centre, an inner city tertiary care teaching hospital that treats $40000 \mathrm{ED}$ patients annually. Eligible subjects included all adult patients $>18$ years of age with a primary diagnosis of asthma who were treated between Jan. 1, 2001, and Dec. 31, 2001. Asthma was considered the primary ED diagnosis if it was the principal reason for the ED encounter. The primary outcome measure was compliance with the CAEP/CTS asthma management guidelines.
This study was approved by the University of Manitoba Research Ethics Board.

\section{Data collection}

A single investigator (R.D.M.) manually reviewed the 1page ED record for every patient seen in the ED during the study period and identified eligible subjects with the discharge diagnosis of asthma, reactive airways disease or related conditions (e.g., status asthmaticus, bronchial asthma, exercise-induced asthma). Manual review was necessary because the hospital's medical records department did not code the ED patient encounters using the International Classification of Diseases or similar classification system; nor was there an ED log or database that consistently included discharge diagnoses for all ED patients.

Investigators reviewed the hospital medical records of all eligible patients identified and documented patient demographics; triage level and asthma severity score; nursing documentation (including vital signs, level of consciousness, weight, medications and peak expiratory flow rate); ED treatments (including agent, dose, route, number of doses used and time of administration for steroids, beta-agonists and anticholinergics); and ED disposition (discharge, admit, transfer, ED observation unit, death in ED). This information was used to determine compliance with national guidelines, ${ }^{7}$ consensus statements ${ }^{6}$ and critical pathways..$^{14}$

Asthma severity (mild, moderate, severe, near death) was determined by correlating clinical documentation from the triage and initial patient assessment with asthma severity descriptions specified in the CAEP/CTS guideline document (Table 1). Patients were placed into the highest severity class for which they had features. Guideline compliance was based on determining whether physicians provided all components of acute treatment recommended for the relevant asthma severity category.

Two investigators (V.F.K. and B.C.) abstracted all data 
independently and entered data into a commercially available database (Access ${ }^{\mathrm{TM}}$, Microsoft Corporation, Redmond, Wash.). Discrepancies were resolved by all 3 investigators by consensus. The final results were exported to a newly created database. If the data element was not found in the patient record, no entry was made in the field and that particular aspect of care was considered not to have been carried out.

\section{Data analysis}

Descriptive statistics for continuous variables were summarized by the mean and standard deviation. Categorical variables were summarized as frequencies. Interobserver reliability of agreement for asthma severity and data elements required in determining guideline compliance was computed using the kappa statistic.

\section{Results}

During the study period, 385 patient encounters resulted in a discharge diagnosis of asthma. The complete medical record was available for review in 372 cases. Twenty-five patients were excluded because they had an alternate primary diagnosis, with asthma as a minor or secondary component. Of these, 6 had a primary diagnosis of bronchitis or upper respiratory infection, 3 had pneumonia, 2 had chronic obstructive pulmonary disease (COPD), 1 had congestive heart failure and 13 had various non-pulmonary problems. Two additional patients were excluded because they were less than 18 years of age. Consequently, this study is based on 345 adult patients with the primary ED diagnosis of asthma. Median age in the study group was 36 years (interquartile range, 26-46 yr), and $32.5 \%$ were men.

Table 2 summarizes patient disposition stratified by asthma severity. Interobserver reliability for asthma severity agreement was 0.95 . Overall compliance with the CAEP/CTS asthma guidelines was $69.6 \%$, (95\% confidence interval [CI] $64.7 \%-74.5 \%$ ), varying from $41.4 \%$ to $88.6 \%$ depending on severity of illness. Table 3 summarizes ED compliance with specific components of the asthma guidelines. Table 4 shows that interobserver relia-

\section{Table 2. Patient disposition stratified by asthma} severity

\begin{tabular}{|c|c|c|c|c|}
\hline \multirow[b]{2}{*}{$\begin{array}{l}\text { Asthma } \\
\text { severity }\end{array}$} & \multirow[b]{2}{*}{$\begin{array}{l}\text { No. of } \\
\text { patients }\end{array}$} & \multicolumn{3}{|c|}{$\begin{array}{c}\text { Disposition of patients, } \\
\text { no. (and \%) }\end{array}$} \\
\hline & & Discharged & $\begin{array}{c}\text { Held in } \\
\text { observation } \\
\text { unit }\end{array}$ & $\begin{array}{c}\text { Admitted } \\
\text { to } \\
\text { hospital }\end{array}$ \\
\hline Near death & 6 & $1(17)$ & $1(17)$ & $4(66)$ \\
\hline Severe & 58 & $40(69)$ & $12(21)$ & $6(10)$ \\
\hline Moderate & 167 & $146(87)$ & $15(9)$ & $6(4)$ \\
\hline Mild & 114 & $111(97)$ & $3(3)$ & $0(0)$ \\
\hline Total & 345 & $298(86)$ & $31(9)$ & $16(5)$ \\
\hline
\end{tabular}

\begin{tabular}{|c|c|c|}
\hline $\begin{array}{l}\text { Asthma } \\
\text { severity }\end{array}$ & Assessment & Treatment \\
\hline Near death & $\begin{array}{l}\text { Exhausted, confused, diaphoretic, cyanotic, silent } \\
\text { chest, decreased respiratory effort, bradycardia, } \\
\mathrm{O}_{2} \text { saturation }<90 \% \text { despite supplemental oxygen. }\end{array}$ & $\begin{array}{l}\text { Paralysis, intubation, continuous inhaled beta- } \\
\text { agonist and anticholinergic agents. } \\
\text { Other interventions for severe illness. }\end{array}$ \\
\hline Severe & $\begin{array}{l}\text { Laboured respirations, agitated, diaphoretic, difficulty } \\
\text { speaking, tachycardic, no relief with prehospital beta- } \\
\text { agonist, } \mathrm{FEV}, / \text { PEFR }<40 \% \text { predicted or previous best. }\end{array}$ & $\begin{array}{l}100 \% \mathrm{O}_{2} \text {, frequent or continuous inhaled beta- } \\
\text { agonist and anticholinergic agents, systemic } \\
\text { corticosteroids, oximetry, arterial blood gas } \\
\text { analysis, cardiac monitoring, chest } x \text {-ray, frequent } \\
\text { physician and nursing reassessment until definite } \\
\text { improvement. }\end{array}$ \\
\hline Moderate & $\begin{array}{l}\text { Dyspnea at rest, cough, congested, chest tightness, } \\
\text { nocturnal symptoms, partial relief from beta-agonist } \\
\text { OR beta-agonist needed more than Q4h; FEV } 1 \text { / PEFR } \\
40 \%-60 \% \text { predicted or previous best. }\end{array}$ & $\begin{array}{l}\text { Supplemental } \mathrm{O}_{2} \text {, systemic corticosteroids. } \\
\text { Inhaled beta-agonist, inhaled anticholinergic } \\
\text { agents may be helpful. }\end{array}$ \\
\hline Mild & $\begin{array}{l}\text { Exertional dyspnea or cough, nocturnal symptoms, } \\
\text { increased beta-agonist use for symptom control, good } \\
\text { response to beta-agonist, FEV } 1 \text { / PEFR }>60 \% \text { predicted } \\
\text { or previous best. }\end{array}$ & $\begin{array}{l}\text { Supplemental } \mathrm{O}_{2} \text { as needed. } \\
\text { Inhaled beta-agonist. }\end{array}$ \\
\hline
\end{tabular}

$\mathrm{FEV}_{1}=$ forced expiratory volume in the first second; PEFR = peak expiratory flow rate. 
bility of guideline compliance assessment was excellent.

\section{Discussion}

This study demonstrates a suboptimal compliance with the CAEP/CTS asthma guidelines. We found that compliance with recommendations for the use of $\beta_{2}$-agonists and anticholinergics was very good, but this was not true for steroids, and this led to suboptimal overall compliance scores. Steroids improve airflow in admitted patients and decrease relapse rates among discharged patients, ${ }^{15-17}$ therefore, better compliance with guidelines for steroid use would dramatically improve overall guideline compliance, and could also improve outcomes for both admitted and discharged patients. Although guideline compliance in this study was suboptimal, it is consistent with documented provider compliance with other similar asthma guidelines..$^{18}$

The guidelines do not define disposition recommendations, but it would seem prudent to admit patients with "severe" or "near-death" asthma. Despite this, most patients with severe asthma and 2 of 6 with near-death asthma were discharged home from the ED. Determining the clinical reasoning for the decision to discharge these patients is beyond the scope of this study and warrants further investigation.

The CAEP/CTS asthma guidelines indicate that patients discharged from the ED should receive discharge instruc- tions and advice for outpatient follow-up. This was documented in less than one-third of patient encounters, although it is possible that patients received verbal instructions. The type and extent of patient education provided by nursing staff cannot be assessed, and no other health care providers were present in this setting during this study period to provide patient education. A prospective study is better suited to assess these factors and confirm whether retrospective findings accurately reflect compliance.

Practice guidelines exist for many common clinical problems, and provider compliance in the ED is variable. ${ }^{19}$ Guideline implementation is difficult, ${ }^{19,20}$ and publication and dissemination of practice guidelines, ${ }^{21,22}$ with or without didactic educational sessions, ${ }^{23}$ are unlikely to change professional practice. Interactive workshops using case studies $^{23,24}$ and real-time, patient-specific prompts have a higher likelihood of success. ${ }^{25}$ Development of local guidelines, utilizing national guidelines as a template, may improve success,,$^{24,26}$ as would retrospective quality improvement efforts based on established benchmarks. ${ }^{19}$

Suboptimal guideline compliance may be associated with several factors, including a lack of guideline and quality improvement (QI) initiatives, absence of explicit performance targets, inadequate involvement of nursing and ancillary staff in the QI process, limited access to reliable data, lack of feedback, and nursing staff shortages. ${ }^{27-29}$ These potential barriers to guideline implementation and

Table 3. Emergency department compliance with specific components of the CAEP / CTS guidelines for the emergency management of asthma in adults

\begin{tabular}{|c|c|c|c|c|c|c|c|}
\hline \multirow[b]{2}{*}{$\begin{array}{l}\text { Asthma } \\
\text { severity }\end{array}$} & \multirow[b]{2}{*}{$\begin{array}{c}\text { No. of } \\
\text { patients }\end{array}$} & \multicolumn{5}{|c|}{ No. (and \%) of patients treated } & \multirow{2}{*}{$\begin{array}{c}\text { Overall ED } \\
\text { compliance, } \\
\text { no. (and \%) } \\
\text { of cases }\end{array}$} \\
\hline & & Intubated & $\begin{array}{l}\text { Beta-agonist } \\
\text { administered }\end{array}$ & $\begin{array}{l}\text { Anticholinergics } \\
\text { administered }\end{array}$ & $\begin{array}{c}\text { Steroid } \\
\text { administered }\end{array}$ & $\begin{array}{l}\text { Chest } x \text {-ray } \\
\text { performed }\end{array}$ & \\
\hline Near death & 6 & $3(50)$ & $6(100.0)$ & $5(83.3)$ & $5(83.3)$ & $6(100.0)$ & $3(50.0) *$ \\
\hline Severe & 58 & NR & $57(98.3)$ & $49(84.5)$ & $42(72.4)$ & $31(53.4)$ & $24(41.4)$ \\
\hline Moderate & 167 & NR & $159(95.2)$ & NR & $114(68.3)$ & NR & $112(67.1)$ \\
\hline Mild & 114 & NR & $101(88.6)$ & NR & NR & NR & $101(88.6)$ \\
\hline
\end{tabular}

CAEP = Canadian Association of Emergency Physicians; CTS = Canadian Thoracic Society; NR = not required as part of guidelilnes ${ }^{*}$ Compliance $=5 / 6(83.3 \%)$ of cases if intubation not considered mandatory.

Table 4. Interobserver reliability (kappa statistic) for guidelines compliance measures

\begin{tabular}{|c|c|c|c|c|c|c|}
\hline $\begin{array}{l}\text { Asthma } \\
\text { severity }\end{array}$ & $\begin{array}{l}\text { No. of } \\
\text { patients }\end{array}$ & $\begin{array}{l}\text { Patient } \\
\text { intubated }\end{array}$ & $\begin{array}{l}\text { Beta }{ }_{2} \text {-agonist } \\
\text { administered }\end{array}$ & $\begin{array}{l}\text { Anticholinergics } \\
\text { administered }\end{array}$ & $\begin{array}{c}\text { Steroid } \\
\text { administered }\end{array}$ & $\begin{array}{l}\text { Chest x-ray } \\
\text { performed }\end{array}$ \\
\hline Near death & 6 & 1.0 & 1.0 & 1.0 & 1.0 & 1.0 \\
\hline Severe & 58 & NR & 0.87 & 0.91 & 0.97 & 1.0 \\
\hline Moderate & 167 & NR & 1.0 & NR & 0.97 & NR \\
\hline Mild & 114 & NR & 0.88 & NR & NR & NR \\
\hline
\end{tabular}


compliance may be overcome by institutional funding to support quality initiatives. Another potential factor is physician training and specialty expertise. A survey of Canadian physicians ${ }^{10}$ showed that those with training beyond general practice were more likely to assess and treat asthma patients according to current asthma guidelines, but further study is necessary to clarify the impact of guideline compliance on actual patient outcomes.

Critical pathways may be used to help implement national guidelines at a local level. These pathways can detail a process of care, outlining the sequence and timing of clinical actions to decrease times to treatment, reduce treatment variation and improve patient outcomes. ${ }^{30}$ Critical pathways have been shown to improve outcomes in patients with pneumonia, ${ }^{31,32}$ femoral fractures, ${ }^{33}$ acute myocardial infarction ${ }^{34,35}$ and asthma. ${ }^{36,37}$

Asthma lends itself well to critical pathway development. Our study demonstrates suboptimal compliance with asthma guidelines. Previous evidence shows that adherence to guidelines improves patient outcomes; ${ }^{7}$ and critical pathways would be applicable to most adult patients with asthma. The ability to abstract valid asthma-related data makes evaluation of a critical pathway feasible and this will be increasingly true as electronic tracking systems, patient records and order entry become more common.

\section{Limitations}

This was a retrospective study conducted in a single ED at a university-affiliated, inner city, tertiary care teaching hospital. Further investigation is required to determine whether these findings are applicable to other settings and patient populations. The study measured guideline compliance but did not assess patient outcomes; nevertheless, these guidelines are considered best practices and have been shown to improve outcomes.

In a retrospective study it is not possible to apply rigorous diagnostic criteria, and some of the patients included in this study may have actually had other respiratory diagnoses, such as COPD. Their inclusion may bias the results because physicians may not apply asthma guidelines to patients with other diagnoses. Finally, there exists the possibility that some interventions may have been provided but not documented, falsely reducing reported guideline compliance.

\section{Conclusions}

Despite publication and dissemination of evidence-based guidelines for the emergency management of acute asthma in adults and evidence showing these guidelines improve patient outcomes, guideline compliance at a university-af- filiated, inner city, tertiary care teaching hospital was suboptimal.

Competing interests: None declared.

Acknowledgements: Supported by a grant from the Health Sciences Centre Medical Staff Council Fellowship Fund.

We thank Dr. Lynne Fulton and Dr. Laurie Morrison for their critical review of this manuscript.

\section{References}

1. Hogg RS, Schecter MT, Montaner JSG. Asthma mortality in Canada, 1946 to 1990. Can Respir J 1995;2:61-6.

2. Sears MR. Epidemiologic trends in asthma. Can Respir J 1996; 3:261-7.

3. Campbell MJ, Cogman GR, Holgate ST, Johnson SL. Age specific trends in asthma mortality in England and Wales, 1983-95: results of an observational study. BMJ 1997;314:1439-40.

4. FitzGerald JM, Macklem PT. Fatal asthma. Annu Rev Med 1996;47:161-8.

5. Krahn MD, Berka C, Langlois P, Detsky AS. Direct and indirect costs of asthma in Canada, 1990. CMAJ 1996;154(6):821-31.

6. Boulet LP, Becker A, Bérubé D, Beveridge R, Ernst P; on behalf of the Canadian Asthma Consensus Group. Management of patients with asthma in the emergency department and in hospital. In: Canadian Asthma Consensus Report, 1999. CMAJ 1999;161(11 suppl):S53-9.

7. Beveridge RC, Grunfeld AF, Hodder RV, Verbeek PR; for the CAEP/CTS Asthma Advisory Committee. Guidelines for the emergency management of asthma in adults. Canadian Association of Emergency Physicians and the Canadian Thoracic Society. CMAJ 1996;155(1):25-37.

8. National Heart, Lung and Blood Institute, National Asthma Education Project. Expert Panel Report: Guidelines for the diagnosis and management of asthma. NIH publ no 91-3042. Bethesda (MD): US Department of Health and Human Services; 1991.

9. Guidelines for management of asthma in adults: II-Acute severe asthma. Statement by the British Thoracic Society, Research Unit of the Royal College of Physicians of London, King's Fund Centre, National Asthma Campaign [published erratum appears in BMJ 1990;301:1272]. BMJ 1990;301:797-800.

10. Grunfeld A, Beveridge RC, Berkowitx J, FitzGerald JM. Management of acute asthma in Canada: an assessment of emergency physician behavior. J Emerg Med 1997;15(4):547-56.

11. Baren JM, Zorc JJ. Contemporary approach to the emergency department management of pediatric asthma. Emerg Med Clin North Am 2002;20(1):115-38.

12. Weiss KB, Sullivan SD. The health economics of asthma and rhinitis. I. Assessing the economic impact. J Allergy Clin Immunol 2001;107(1):3-8.

13. Sullican SD, Weiss KB. The health economics of asthma and rhinitis. II. Assessing the value of interventions. J Allergy Clin Immunol 2001;107(2):203-10. 
14. Boulet LP, Becker A, Bérubé D, Beveridge R, Ernst P; on behalf of the Canadian Asthma Consensus Group. Review. In: Canadian Asthma Consensus Report, 1999. CMAJ 1999;161(11 suppl):S60-1.

15. Rowe BH, Keller JL, Oxman AD. Effectiveness of steroid therapy in acute exacerbations of asthma: a meta-analysis. Am J Emerg Med 1992;10:301-10.

16. Fanta $\mathrm{CH}$, Rossing TH, McFadden ERJ. Glucocorticoids in acute asthma: a critical controlled trial. Am J Med 1983;74:845-51.

17. Rowe BH, Spooner CH, Ducharme FM, Bretslaff JA, Bota GW. The effectiveness of corticosteroids in the treatment of acute exacerbations of asthma: a meta-analysis of their effect on relapse rate following acute assessment [Cochrane review]. In: The Cochrane Library; Issue 4, 1998. Oxford: Update Software.

18. Scribano PV, Lerer T, Kennedy D, Cloutier M. Provider adherence to a clinical practice guideline for acute asthma in a pediatric emergency department. Acad Emerg Med 2001;8(12): 1147-52.

19. Burstin HR, Conn A, Setnik G, Rucker DW, Cleary PD, O’Neil AC, et al. Benchmarking and quality improvement: the Harvard Emergency Department Quality Study. Am J Med 1999; 107(5):437-9.

20. Greco PH, Eisenberg JM. Changing physicians' practices. N Engl J Med 1993;329:1271-8.

21. Freemantle N, Harvey EL, Wolf F, Grimshaw JM, Grilli R, Bero LA. Printed educational materials: effects on professional practice and health are outcomes [Cochrane review]. In: The Cochrane Library; Issue 2, 2002. Oxford: Update Software.

22. Oxman AD, Thomson MA, Davis DA, Haynes RB. No magic bullets: a systematic review of 102 trials of interventions to improve professional practice. CMAJ 1995;153:1423-31.

23. Thomson O'Brien MA, Freemantle N, Oxman AD, Wolf F, Davis DA, Herrin J. Continuing education meetings and workshops: effects on professional practice and health care outcomes [Cochrane review]. In: The Cochrane Library; Issue 2, 2002. Oxford: Update Software.

24. Greenberg LW, Jewett LS. The impact of two educational techniques on physician knowledge, performance, and patient care. Mobius 1984;4:51-3.

25. Feder G, Griffith C, Highton C, Eldridge S, Spence M, Southgate L. Do clinical guidelines introduced with practice based education improve care of asthmatic and diabetic patients? A randomized controlled trial in general practices in east London. BMJ 1995;311:1473-8.
26. Grimshaw JM, Russell IT. Effect of clinical practice guidelines on medical practice: a systematic review of rigorous evaluations. Lancet 1993;342:1317-22.

27. Bradley EH, Holmboe ESW, Mattera JA, Roumanis SA, Radford MJ, Krumholz AM. A qualitative study of increasing beta blocker use after myocardial infarction: Why do some hospitals succeed? JAMA 2001;285:2604-11.

28. Graff L, Stevens C, Spaite D, Foody JA. Measuring and improving quality in emergency medicine. Acad Emerg Med 2002;9:1091-107.

29. Balas EA, Austin SM, Mitchell J, Ewigman BG, Bopp KD, Brown GD. The clinical value of computerized information services: a review of 98 randomized clinical trials. Arch Fam Med 1996;5:271-8.

30. Every NR, Hochman J, Becker R, Kopecky S, Cannon CP; for the Committee on Acute Cardiac Care, Council on Clinical Cardiology, American Heart Association. Critical pathways: a review. Circulation 2000;101:461-5.

31. Sperry S, Birdsall C. Outcomes of a pneumonia critical path. Nurs Econ 1994;12(6):332-9, 345.

32. Benenson R, Magalski A, Cavanaugh S, Williams E. Effects of a pneumonia clinical pathway on time to antibiotic treatment, length of stay, and mortality. Acad Emerg Med 1999;26:421-7.

33. Tallis G, Balla JI. Critical path analysis for the management of fractured neck of femur. Aust J Public Health 1995;19(2):155-9.

34. Montague T, Taylor L, Martin S, Barnes M, Ackman M, Tsuyuki R, et al. Can practice patterns and outcomes be successfully altered? Examples from cardiovascular medicine. The Clinical Quality Improvement Network (CQIN) Investigators. Can J Cardiol 1995;11(6):487-92.

35. Influence of a critical path management tool in the treatment of acute myocardial infarction. Clinical Quality Improvement Network Investigators. Am J Manag Care 1998;4(9):1243-51.

36. Emond SD, Woodruff PG, Lee EY, Singh AK, Camargo CA Jr. Effect of an emergency department care program on acute asthma care. Ann Emerg Med. 1999;34(3):321-5.

37. Akerman MJ, Sinert R. A successful effort to improve asthma care outcome in an inner-city emergency department. J Asthma 1999;36(3):295-303.

Correspondence to: Dr. Russell D. MacDonald, Ontario Air Ambulance, 1120 Finch Ave. W, Ste. 405, Toronto ON M3J 3H7; 416 667-2200, fax 416 667-2229, rmacdonald@ basehospital.on.ca 